\title{
PENGARUH CURRENT RATIO (CR), DEBT TO EQUITY RATIO (DER), DAN TOTAL ASSETS TURNOVER (TATO) TERHADAP PERTUMBUHAN LABA PADA PERUSAHAAN MANUFAKTUR SEKTOR INDUSTRI DASAR DAN KIMIA YANG TERDAFTAR DI BURSA EFEK INDONESIA TAHUN 2017-2020
}

\author{
Yuslinda Nasution ${ }^{1}$, Guston Sitorus ${ }^{2}$ \\ Universitas Satya Negara Indonesia ${ }^{1.2}$ \\ yuslindanst12@gmail.com ${ }^{1}$,humas@husni.ac.id ${ }^{2}$
}

\begin{tabular}{lcl}
\hline Received: & Accepted: & Published: \\
1 Januari 2022 & 15 Februari 2022 & 22 Februari 2022 \\
\hline
\end{tabular}

\begin{abstract}
ABSTRAK
Penelitian ini dilakukan untuk menguji pengaruh Current Ratio (CR), Debt to Equity Ratio (DER), dan Total Asset Turnover (TATO) terhadap pertumbuhan laba. Populasi pada penelitian ini adalah seluruh perusahaan manufaktur sektor dasar dan kimia yang terdaftar di Bursa Efek Indonesia Periode Tahun 2017 - 2020. Teknik sampling yang digunakan adalah purposive sampling dengan sampel sebanyak 32 perusahaan. Metode analisis yang digunakan dalam penelitian ini yaitu analisis deskriptif dan regresi linier berganda. Jenis data dalam penelitian ini menggunakan data sekunder. Hasil penelitian ini menunjukkan bahwa pengaruh Current Ratio (CR), Debt to Equity Ratio (DER), dan Total Asset Turnover (TATO) terhadap pertumbuhan laba sebesar 30\%. Secara parsial Current Ratio (CR) dan Debt to Equity Ratio (DER) tidak berpengaruh signifikan terhadap pertumbuhan laba, sedangkan Total Asset Turnover (TATO) berpengaruh signifikan terhadap pertumbuhan laba pada perusahaan manufaktur sektor dasar dan kimia yang terdaftar di Bursa Efek Indonesia Periode Tahun 2017 -2020 .
\end{abstract}

Kata kunci : Pertumbuhan Laba, Current Ratio (CR), Debt to Equity Ratio (DER), dan Total Asset Turnover (TATO)

\section{ABSTRACT}

This research was conducted to examine the effect of Current Ratio (CR), Debt to Equity Ratio (DER), and Total Asset Turnover (TATO) on profit growth. The population in this study were all basic and chemical manufacturing companies listed on the Indonesia Stock Exchange for the 2017-2020 period. The sampling technique used was purposive sampling with a sample of 32 companies. The analytical method used in this research is descriptive analysis and multiple linear regression. The type of data in this study uses secondary data. The results of this study indicate that the effect of Current Ratio (CR), Debt to Equity Ratio (DER), and Total Asset Turnover (TATO) on profit growth is 30\%. Partially Current Ratio (CR) and Debt to Equity Ratio (DER) have no significant effect on profit growth, while Total Asset Turnover (TATO) has a significant effect on profit growth in basic and chemical manufacturing companies listed on the Indonesia Stock Exchange for the 2017 period. - 2020.

Keywords : Profit Growth, Current Ratio (CR), Debt to Equity Ratio (DER), and Total Asset Turnover (TATO) 


\section{PENDAHULUAN}

Kekayaan yang terkandung dalam alam sangat meluap di Indonesia menjadi suatu peluang bagi industri - industri yang bergerak pada bidang pengolahan. Industri pengolahan merupakan perusahaan manufaktur. Pertumbuhan pada industri manufaktur di saat ini semakin pesat menyebabkan adanya kompetisi persaingan industri manufaktur di Indonesia yang semakin ketat yang diakibatkan oleh tingginya permintaan tingkatan konsumen terhadap produk dengan demikian perusahaan manufaktur saat ini memiliki peran dalam menopang pertumbuhan perekonomian di Indonesia (Solihah, 2015). Industri manufaktur merupakan penyangga yang bersifat fundamental bagi perkembangan perekonomian nasional. Kementerian perindustrian mencatat bahwa pada tahun 2018 tujuh sektor yang mendapatkan investasi yang sangat besar, yaitu sektor makanan dan minuman, logam dasar, alat angkutan, kimia, mesin dan perlengkapan, farmasi, serta elektronik. Pada tahun 2018 peran serta terhadap Produk Domestik Bruto (PDB) sebesar 33\%. Berdasarkan laporan Nur Qolbi (2020) yang di lansir dari Kontan.co.id sepanjang tahun 2020 indeks merosot pada tiap sektornya hingga 31,25\%, penurunan terdalam indeks sektoral pada industri dasar dan kimia yaitu sebesar $43,53 \%$ penurunan ini di dominasi oleh sub sektor semen, pakan ternak, pulp dan kertas, keramik dan porselin hingga bahan kimia penurunan disebabkan kerena harga saham-saham sebelumnya sudah tergolong mahal pada penghuni indeks tersebut seperti PT Chandra Asri Petrochemical Tbk tumbuh 85,27\% dan PT Barito Pacific Tbk yang sepanjang 2019 melesat 226,84\%.

Perusahaan perlu memiliki daya saing untuk berkompetitif dengan perusahaan lain dalam menjamin kelangsungan hidupnya, maka perusahaan mengupayakan untuk selalu menambah kinerjanya termasuk kinerja keuangannya (Astutik \& Anggraeny, 2019). Laporan keuangan digunakan untuk mengawasi kinerja keuangan dan berguna untuk memperoleh informasi keuangan,

khususnya bagi investor yang berminat untuk berinvestasi pada suatu perusahaan untuk menilai pencapaiannya (Sri Wahyuni,2018). Pertumbuhan laba yang baik, akan memberikan keuangan yang positif pada perusahaan, dan nantinya akan menaikkan nilai pada perusahaan (Sihura \& Gaol, 2016). Terdapat beberapa faktor yang mempengaruhi pertumbuhan laba di antaranya rasio likuiditas dengan indikator Current Ratio (CR), rasio solvabilitas dengan indikator Debt To Equity Ratio (DER), dan rasio aktivitas dengan indikator Total Asset Turnover (TATO). Current Ratio (CR) yaitu rasio likuiditas mendeskripsikan tentang perhitungan proporsi antara harta lancar yang ada dengan utang jangka pendek yang harus dilunasi. Tingginya nilai Current Ratio maka memberikan dampak negative terhadap kompetensi perusahaan untuk menghasilkan surplus. Debt to Equity Ratio (DER) yaitu rasio solvabilitas mendeskripsikan apakah equity mampu untuk memenuhi utang pada perusahaan. DER yang tinggi menandakan besarnya penggunaan utang perusahaan kepada pihak eksternal. Utang tersebut dapat menurunkan laba yang akan di terima oleh perusahaan. Total Asset Turnover (TATO) yaitu rasio aktivitas yang memiliki fungsi mendeteksi sejauh mana perusahaan dalam memberikan sumber dananya kepada pihak luar (kreditor) terhadap aktiva perusahaan. Perputaran total asset yang cepat akan menimbulkan cepatnya dalam memperoleh keuntungan.

Tabel 1

Nilai CR, DER, dan TATO terhadap Pertumbuhan Laba PT Arwana Citramulia Tbk Tahun 2017-2020

\begin{tabular}{|l|c|c|c|c|c|c|}
\hline \multirow{2}{*}{ Nama Perusahaan } & \multirow{2}{*}{ Kode } & Ratio & \multicolumn{3}{|c|}{ Tahun } \\
\cline { 3 - 7 } & & & 2017 & 2018 & 2019 \\
\hline $\begin{array}{l}\text { PT. Arwana } \\
\text { Citramulia Tbk }\end{array}$ & ARNA & CR (\%) & DER (\%) & 563 & 174 & 174 \\
\cline { 3 - 7 }
\end{tabular}




\begin{tabular}{|c|c|c|c|c|c|c|}
\hline \multirow{4}{*}{ Nama Perusahaan } & \multirow{4}{*}{ Kode } & \multirow[b]{2}{*}{ Ratio } & \multicolumn{4}{|c|}{ Tahun } \\
\hline & & & 2017 & 2018 & 2019 & 2020 \\
\hline & & TATO $(\mathrm{x})$ & 1,08 & 1,19 & 1,20 & 1,12 \\
\hline & & Pertumbuhan Laba (\%) & 34 & 29 & 38 & 50 \\
\hline
\end{tabular}

Tahun 2018 Current Ratio (CR) meningkat sebesar 11\% namun pertumbuhan laba terjadi penurunan $5 \%$ dimana terdapat ketidaksesuaian dengan teori, hal ini menunjukkan rasio lancar yang semakin tinggi dapat menyebabkan terdapat menganggurnya saldo kas dan mengakibatkan hasil keuntungan berkurang. Di tahun 2018 DER menurun 5\% dan pertumbuhan laba terjadi penurunan $5 \%$ peristiwa ini menggambarkan adanya fenomena gap dan pada tahun 2020 Total Assets Turnover (TATO) menurun tetapi pertumbuhan laba meningkat sebesar $12 \%$. Hal ini menunjukkan adanya fenomena dimana Total Assets Turnover (TATO) yang meningkat seharusnya pertumbuhan laba ikut meningkat artinya Pertambahan nilai TATO tidak selalu terjadi peningkatan pertumbuhan laba. Meningkatnya perputaran total aset yang mendorong peningkatan penjualan maka laba bersih belum tentu meningkat.

Tabel 2

Nilai CR, DER, dan TATO terhadap Pertumbuhan Laba PT. Impack Pratama Industri Tbk Tahun 2017-2020

\begin{tabular}{|c|c|c|c|c|c|c|}
\hline \multirow[b]{2}{*}{ Nama Perusahaan } & \multirow{2}{*}{ Kode } & \multirow[b]{2}{*}{ Ratio } & \multicolumn{4}{|c|}{ Tahun } \\
\hline & & & 2017 & 2018 & 2019 & 2020 \\
\hline \multirow{4}{*}{$\begin{array}{l}\text { PT. Impack Pratama } \\
\text { Industri Tbk }\end{array}$} & \multirow[t]{4}{*}{ IMPC } & $\mathrm{CR}(\%)$ & 361 & 356 & 245 & 207 \\
\hline & & $\operatorname{DER}(\%)$ & 78 & 73 & 78 & 84 \\
\hline & & TATO $(\mathrm{x})$ & 0,52 & 0,59 & 0,60 & 0,67 \\
\hline & & Pertumbuhan Laba (\%) & -27 & 16 & -12 & 24 \\
\hline
\end{tabular}

Tahun 2018 dan 2020 Current Ratio (CR) menurun masing masing dengan nilai 4\% dan 38\% sedangkan pertumbuhan laba meningkat. Current Ratio yang menurun disebabkan oleh besarnya peningkatkan utang lancar di bandingkan dengan aktiva lancar. Pada tahun 2019 Total asset turnover meningkat tetapi terjadi penurunan pertumbuhan laba. Mendefinisikan adanya fenomena dimana Total Assets Turnover (TATO) yang menurun seharusnya menyebabkan pertumbuhan laba ikut menurun. Tahun 2020 Debt to Equity Ratio terjadi peningkatan 6\% namun pertumbuhan laba ikut mengalami peningkatan. Hal ini menunjukkan pemakaian utang yang terlalu tinggi membahayakan perusahaan.

Tabel 3

Nilai CR, DER, dan TATO terhadap Pertumbuhan Laba PT. Charoen Pokphand IndonesiaTbk Tahun 2017-2020

\begin{tabular}{|c|c|c|c|c|c|c|}
\hline \multirow{2}{*}{ Nama Perusahaan } & \multirow{2}{*}{ Kode } & \multirow{2}{*}{ Ratio } & \multicolumn{4}{|c|}{ Tahun } \\
\hline & & & 2017 & 2018 & 2019 & 2020 \\
\hline \multirow{4}{*}{$\begin{array}{l}\text { PT. Charoen Pokphand } \\
\text { IndonesiaTbk }\end{array}$} & \multirow[t]{4}{*}{ CPIN } & CR (\%) & 232 & 298 & 254 & 253 \\
\hline & & DER (\%) & 56 & 43 & 39 & 33 \\
\hline & & TATO $(\mathrm{x})$ & 2,01 & 1,95 & 1,46 & 1,36 \\
\hline & & $\begin{array}{l}\text { Pertumbuhan } \\
\text { Laba (\%) }\end{array}$ & 12 & 82 & -20 & 6 \\
\hline
\end{tabular}

tahun 2019 Debt to Equity Ratio menurun 4\% namun pertumbuhan laba ikut menurun dari 82 menjadi -20\%. Pada tahun 2020 Current Ratio (CR) menurun 1\% namun membuat pertumbuhan laba meningkat dari -20\% menjadi 6\%. Pada tahun 2020 Total Asset Turnover (TATO) menurun dengan nilai 1,36 dan pertumbuhan laba meningkat $6 \%$. Ini menandakan ketidaksesuaian antara uraian yang telah di paparkan dan terdapat fenomena. Berdasarkan fenomena tersebut dengan ini penulis tertarik untuk melakukan penelitian, dengan mengambil judul : PENGARUH CURRENT RATIO (CR), DEBT TO EQUITY RATIO (DER), DAN 


\section{TOTAL ASSET TURNOVER (TATO) TERHADAP PERTUMBUHAN LABA PADA PERUSAHAAN MANUFAKTUR SEKTOR INDUSTRI DASAR DAN KIMIA YANG TERDAFTAR DI BURSA EFEK INDONESIA TAHUN 2017 - 2020. \\ KAJIAN TEORI}

Dalam penelitian ini, penulis mengambil dan mencari referensi - referensi yang bersangkutan dengan topik yang diangkat melalui buku - buku, maupun jurnal atau skripsi, sehingga dapat diketahui perbedaan dan kontribusi penulis, diantaranya :

1. Pertumbuhan Laba

Kasmir (2018:107) mendeskripsikan kesanggupan perusahaan untuk mendapatkan keuntungan dalam melakukan aktivitasnya. Adapun rumus pertumbuhan laba yaitu:

$\mathrm{PL}=\underline{\text { Laba tahun }}_{\mathrm{t}}-\mathrm{Laba}_{\text {tahun }} \mathrm{t}-1$

Laba tahun $\mathrm{t}-1$

2. Current Ratio

Kasmir (2018:134) mengemukakan bahwa Current Ratio (CR) ialah rasio yang berfungsi menaksir sejauh mana kapabilitas perusahaan untuk memenuhi seluruh pinjaman atau utang jangka pendek yang mesti diselesaikan saat penagihan. Tingginya nilai Current Ratio mampu memproyeksikan jaminan kepada kreditor dalam jangka waktu yang panjang yang baik. Adapun rumus Current Ratio (CR) yaitu:

$\mathrm{CR}=\quad$ Aktiva Lancar

Utang Lancar

3. Debt to Equity Ratio

Hery (2018:168) mendeskripsikan DER untuk membandingkan antara total utang terhadap equity yang ada. Rasio ini dapat digunakan untuk menilai proporsi antara total dana yang di peroleh dari pinjaman (utang) dengan total dana yang dimiliki perusahaan. Tingginya rasio maka modal yang dimiliki lebih kecil dari pada utang - utang yang harus dilunasi. Adapun rumus DER yaitu :

DER $=$ Total Utang

Total Modal

4. Total Assets Turnover

Fahmi (2020:104) ialah untuk mengetahui seberapa jauh seluruh asset perusahaan terjadi perputaran secara efektif. Semakin besar perputaran aktivanya maka pengelolaan aktiva perusahaan semakin efektif. Adapun rumusnya yaitu :

TATO $=\underline{\text { Penjualan }}$

Total Asset

\section{HIPOTESIS}

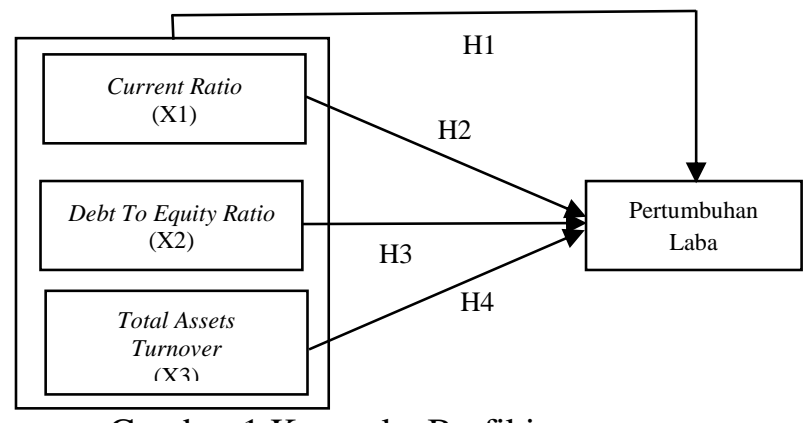

Gambar 1 Kerangka Berfikir 
$\mathrm{H}_{1}$ : Terdapat pengaruh Current Ratio (CR), Debt to Equity Ratio (DER), dan Total Asset Turnover (TATO) berpengaruh secara simultan terhadap Pertumbuhan Laba.

$\mathrm{H}_{2}$ : Terdapat pengaruh Current Ratio (CR) berpengaruh terhadap Pertumbuhan Laba.

$\mathrm{H}_{3}$ : Terdapat pengaruh Debt to Equity Ratio (DER) berpengaruh terhadap Pertumbuhan Laba.

$\mathrm{H}_{4}$ : Terdapat pengaruh Total Assets Turnover (TATO) berpengaruh terhadap Pertumbuhan Laba.

\section{METODE PENELITIAN}

\section{Waktu dan Tempat Penellitian}

Dilaksanakan waktu pada penelitian selama enam bulan, tepatnya pada bulan September 2021 sampai Februari 2022. Tempat dilakukannya penelitian yaitu pada Perusahaan Manufaktur Sektor Industri Dasar dan Kimia yang terdaftar di BEI pada tahun 2017 - 2020.

\section{Desain Penelitian}

Dilaksanakannya penelitian memakai penelitian kausal. Studi kausal ialah studi yang mengetahui pengaruh satu variabel atau lebih variabel independen terhadap variabel dependen.

\section{Populasi dan Sampel}

Populasi yang digunakan ialah seluruh perusahaan manufaktur sektor industri dasar dan kimia yang terdaftar di BEI pada tahun 2017 - 2020 jumlah populasi penelitian ini yaitu sebanyak 77 Perusahaan. maka sampel yang di ambil sebanyak 32 perusahaan manufaktur sektor dasar dan kimia yang terdaftar di BEI pada tahun 2017 - 2020.

\section{Jenis dan Sumber Data}

Data sekunder yang di pakai dalam penelitian ini yang dimana data tersebut sudah diolah terlebih dahulu dan di sajikan oleh pihak lain. Data ini menggunakan laporan keuangan tahunan perusahaan manufaktur sektor dasar dan kimia yang sumbernya melalui website Bursa Efek Indonesia (www.idx.co.id).

\section{ANALISIS DAN PEMBAHASAN}

\section{Analisis Deskriptif}

Tabel 2

Uji Analisis Deskriptif

\begin{tabular}{|c|c|c|c|c|c|}
\hline \multicolumn{6}{|c|}{ Descriptive Statistics } \\
\hline & $\mathrm{N}$ & Min & $\operatorname{Max}$ & Mean & $\begin{array}{c}\text { Std } \\
\text { Deviation }\end{array}$ \\
\hline Current Ratio & 36 & 1,02 & 5,10 & 2,5178 & 0,88551 \\
\hline $\begin{array}{c}\text { Debt to Equity } \\
\text { Ratio }\end{array}$ & 36 & 0,13 & 0,84 & 0,4800 & 0,21851 \\
\hline $\begin{array}{l}\text { Total Assets } \\
\text { Turnover }\end{array}$ & 36 & 0,31 & 1,20 & 0,7817 & 0,25350 \\
\hline $\begin{array}{c}\text { Pertumbuhan } \\
\text { Laba }\end{array}$ & 36 & $\begin{array}{c}- \\
0,63\end{array}$ & 1,40 & 0,1786 & 0,53476 \\
\hline $\begin{array}{c}\text { Valid N } \\
\text { (listwise) }\end{array}$ & 36 & & & & \\
\hline
\end{tabular}

Variabel CR diketahui nilai minimun yaitu diperoleh PT Suparma Tbk (SPMA) dengan nilai 1,02 pada tahun 2017. Sedangkan nilai maksimum CR di peroleh PT Intanwijaya Internasional Tbk (INCI) dengan nilai 5,10 pada tahun 2017. Nilai mean Current Ratio tahun 2017 - 2020 adalah sebesar 2,5178 dan standar deviasi yaitu 0,88551 .

Variabel DER diketahui nilai minimum yaitu diperolah PT Intanwijaya Internasional Tbk (INCI) dengan nilai 0,13 pada tahun 2017. Sedangkan nilai maksimum Debt to Equity Ratio yaitu diperoleh PT Impack Pratama Industri Tbk (IMPC) dengan nilai 0,84 pada tahun 2020. 
Volume 6 No 2 Februari 2022

P-ISSN : 2528-7044

E-ISSN : 2809-5103

DOI: https://doi.org/10.54964/manajemen/

Nilai mean DER tahun 2017 - 2020 adalah sebesar 0,4800 dan standar deviasi yaitu 0,21851 Variabel Pertumbuhan Laba diketahui nilai minimum yaitu diperolah PT. Semen Baturaja Tbk (SMBR) dengan nilai -0,63 pada tahun 2020. Sedangkan nilai maksimum Pertumbuhan Laba yaitu diperoleh PT Mark Dynamics Indonesia (MARK) dengan nilai 1,40 pada tahun 2017. Nilai mean Pertumbuhan Laba tahun 2017 - 2020 adalah sebesar 0,1786 dan standar deviasi yaitu 0,53476 .

\section{Uji Asumsi Klasik \\ Uji Normalitas}

Tabel 3

Uji Normalitas

\begin{tabular}{|c|c|c|c|c|c|}
\hline \multicolumn{6}{|c|}{ One-Sample Kolmogorov-Smirnov Test } \\
\hline & & $\mathrm{CR}$ & DER & $\begin{array}{c}\text { TAT } \\
\text { O }\end{array}$ & $\begin{array}{l}\text { Pertumbu } \\
\text { han Laba }\end{array}$ \\
\hline \multicolumn{2}{|l|}{$\mathrm{N}$} & 36 & 36 & 36 & 36 \\
\hline \multirow[t]{2}{*}{ Normalarameters } & Mean & 2,5178 & 0,4800 & $\begin{array}{r}0,78 \\
17\end{array}$ & 0,1786 \\
\hline & Std.Deviation & 0,88551 & 0,21851 & $\begin{array}{r}0,25 \\
350 \\
\end{array}$ & 0,53476 \\
\hline \multirow[t]{3}{*}{$\begin{array}{l}\text { Most } \\
\text { ExtremDifference }\end{array}$} & Absolute & 0,106 & 0,132 & $\begin{array}{r}0,13 \\
2\end{array}$ & 0,077 \\
\hline & Positif & 0,106 & 0,132 & $\begin{array}{r}0,07 \\
0 \\
\end{array}$ & 0,077 \\
\hline & Negatif & $-0,075$ & $-0,086$ & $\begin{array}{r}- \\
0,12 \\
3\end{array}$ & $-0,066$ \\
\hline \multicolumn{2}{|c|}{ Test Statistic } & 0,106 & 0,132 & $\begin{array}{r}0,12 \\
3\end{array}$ & 0,077 \\
\hline \multicolumn{2}{|c|}{ Asymp. Sig (2-tailed) } & $0,200^{\mathrm{c.d}}$ & $0,119^{\mathrm{c}}$ & $\begin{array}{r}0,18 \\
5^{\mathrm{c}}\end{array}$ & $0,200^{\mathrm{c} . \mathrm{d}}$ \\
\hline
\end{tabular}

Pengujian normalitas One - Sampel Kolmogrov-Smirnov pada variabel CR, DER, TATO dan Pertumbuhan Laba dengan nilai signifikansi > dari 0,05 sehingga dapat dikatakan bahwa data penelitian dari masing - masing variabel sudah terdistribusi normal.

\section{Uji Multikoliniearitas}

Tabel 4

Uji Multikoliniearitas

\begin{tabular}{|l|r|r|}
\hline \multirow{2}{*}{ Model } & \multicolumn{2}{|c|}{ Collinearity Statistics } \\
\cline { 2 - 3 } & Tolerance & \multicolumn{1}{|c|}{ VIF } \\
\hline 1 (Constant) & & \\
\hline CR & 0,746 & 1,341 \\
\hline DER & 0,756 & 1,323 \\
\hline TATO & 0,982 & 1,019 \\
\hline
\end{tabular}

Berdasarkan tabel hasil dari output SPSS melihatkan besarnya nilai (VIF) pada variabel independent yaitu tolerance $>0,10$ dan nilai VIF $<10$ kesimpulannya yaitu antar variabel independent tidak terjadi multikolinearitas.

Maka penjelasannya adalah:

1) Variabel $\mathrm{CR}$ tolerance $0,746>0,10$ dan VIF $1,341<10$ sehingga tidak terjadi multikolinearitas 


\section{Jurnal Manajemen USNI}

Volume 6 No 2 Februari 2022

P-ISSN : 2528-7044

E-ISSN : 2809-5103

DOI: https://doi.org/10.54964/manajemen/

2) Variabel DER tolerance $0,756>0,10$ dan VIF $1,323<10$ sehingga tidak terjadi multikolinearitas

3) Variabel TATO tolerance 0,982 > 0,10 dan VIF 1,019 < 10 sehingga tidak mengalami multikolinearitas

\section{Uji Heteroskedastisitas}

Tabel 5

Uji Heteroskedastisitas

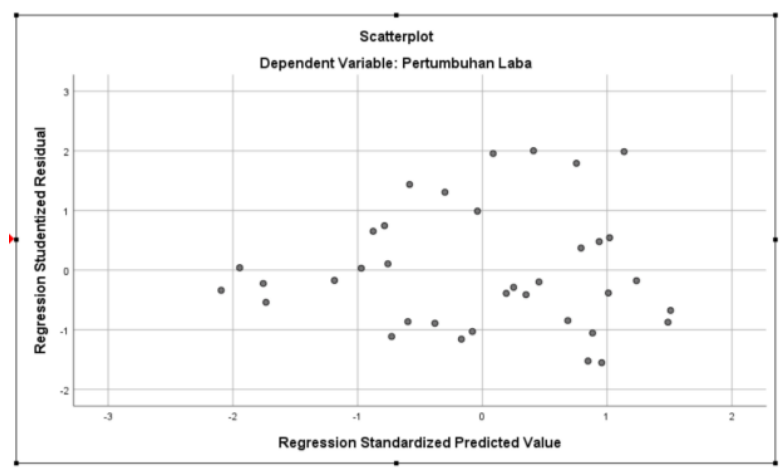

Grafik scatterplot menunjukkan bahwa model penelitian tidak mengalami gangguan heterokedastisitas, karena grafik scatterplot tidak membentuk pola pada grafik tersebut.

\section{Uji Autokolerasi}

Tabel 6

Uji Autokorelasi

\begin{tabular}{|l|r|}
\hline \multicolumn{2}{|c|}{ Runs Test } \\
\hline & \multicolumn{2}{|c|}{$\begin{array}{c}\text { Unstandardized } \\
\text { Residual }\end{array}$} \\
\hline Test Value & \multicolumn{1}{c}{ r } \\
\hline Cases < Test Value & 18 \\
\hline Cases >= Test Value & 18 \\
\hline Total Cases & 36 \\
\hline Number of Runs & 17 \\
\hline Z & $-0,507$ \\
\hline Asymp. Sig. (2-tailed) & 0,612 \\
\hline a. Median & \\
\hline
\end{tabular}

Hasil run test memperlihatkan nilai Asymp. Sig. (2-tailed) $=0,612>$ dari 0,05 yang berarti diartikan bahwa tidak terdapat autokorelasi antar nilai residual. 


\section{Analisis Regresi Linier Berganda}

Tabel 7

Analisis Regresi Liniear Berganda

\begin{tabular}{|c|c|c|c|c|c|c|c|c|}
\hline \multicolumn{9}{|c|}{ Coefficients $^{\mathrm{a}}$} \\
\hline & \multirow{2}{*}{ Model } & \multicolumn{2}{|c|}{$\begin{array}{l}\text { Unstandardized } \\
\text { Coefficients }\end{array}$} & \multirow{2}{*}{$\begin{array}{c}\begin{array}{r}\text { Standardized } \\
\text { Coefficients }\end{array} \\
\text { Beta }\end{array}$} & \multirow{2}{*}{$\mathrm{T}$} & \multirow{2}{*}{ Sig. } & \multicolumn{2}{|c|}{$\begin{array}{l}\text { Collinearity } \\
\text { Statistics }\end{array}$} \\
\hline & & B & $\begin{array}{l}\text { Std. } \\
\text { Error }\end{array}$ & & & & $\begin{array}{c}\text { Tolera } \\
\text { nce }\end{array}$ & VIF \\
\hline \multirow[t]{4}{*}{1} & (Constant) & $-0,722$ & 0,478 & & $-1,510$ & 0,141 & & \\
\hline & $\mathrm{CR}$ & 0,026 & 0,099 & 0,043 & 0,264 & 0,793 & 0,746 & 1,341 \\
\hline & DER & $-0,283$ & 0,398 & $-, 0,116$ & $-0,712$ & 0,482 & 0,756 & 1,323 \\
\hline & TATO & 1,241 & 0,301 & 0,588 & 4,127 & 0,000 & 0,982 & 1,019 \\
\hline
\end{tabular}

Berdasarkan tabel maka persamaan regresi berganda sebagai berikut : $\mathrm{Y}=-0,722+0,026 \mathrm{X} 1-0,283 \mathrm{X} 2+1,241 \mathrm{X} 3+\mathrm{ei}$

a. Konstanta $=-0,722$

Apabila variabel CR (X1), DER (X2), TATO (X3) memiliki nilai 0, maka variabel pertumbuhan laba $(\mathrm{Y})$ sebesar $-0,722$

b. Koefisien CR $(\mathrm{X} 1)=0,026$

Nilai koefisien regresi CR yang naik sebesar 1 satuan, dengan asumsi variabel - variabel lain adalah tetap, berarti variabel pertumbuhan laba ikut meningkat sebesar 0,026

c. Koefisien DER (X2) = -0,283

Nilai koefisien regresi DER yang naik sebesar 1 satuan, dengan asumsi variabel - variabel lain adalah tetap, maka variabel pertumbuhan laba akan menurun sebesar -0,283

d. Koefisien TATO $(\mathrm{X} 3)=1,241$

Nilai koefisien regresi TATO yang naik sebesar 1 satuan, dengan asumsi variabel - variabel lain adalah tetap, maka variabel pertumbuhan laba ikut meningkat sebesar 1,241

\section{Uji F (Simultan)}

Tabel 8

Uji F (Simultan)

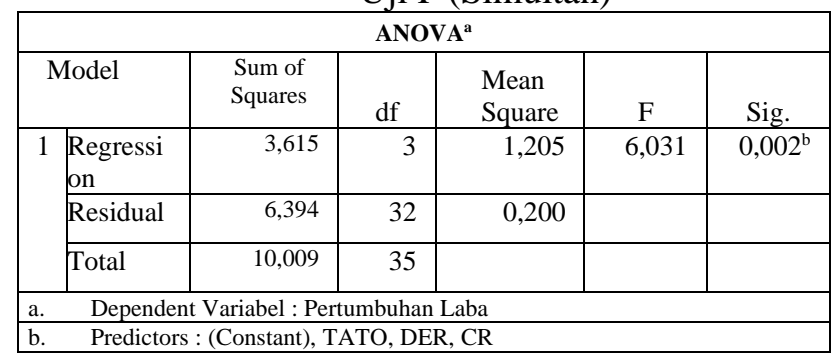


Signifikannya sebesar $0,002^{\mathrm{b}}<\operatorname{sig} \alpha(0,05)$ dan uji F-hitung sebesar F-hitung 6,031 > F-tabel 2,89. Ini berarti bahwa Ho ditolak dan Ha diterima. Maka terdapat pengaruh signifikan secara bersama - sama (simultan) antara tingkat CR,DER dan TATO terhadap pertumbuhan laba.

\section{Uji t (Parsial)}

Tabel 9

Uji t (Parsial)

\begin{tabular}{|c|c|c|c|c|c|c|c|c|}
\hline \multicolumn{9}{|c|}{ Coefficients $^{\mathrm{a}}$} \\
\hline & & \multicolumn{2}{|c|}{$\begin{array}{l}\text { Unstandardized } \\
\text { Coefficients }\end{array}$} & \multirow{2}{*}{$\begin{array}{c}\begin{array}{r}\text { Standardized } \\
\text { Coefficients }\end{array} \\
\text { Beta }\end{array}$} & \multirow{2}{*}{$\mathrm{T}$} & \multirow{2}{*}{ Sig. } & \multicolumn{2}{|c|}{$\begin{array}{l}\text { Collinearity } \\
\text { Statistics }\end{array}$} \\
\hline \multicolumn{2}{|c|}{ Model } & B & $\begin{array}{c}\text { Std. } \\
\text { Error }\end{array}$ & & & & $\begin{array}{c}\text { Toleran } \\
\text { ce }\end{array} \mid$ & VIF \\
\hline \multirow[t]{4}{*}{1} & (Constant) & $-0,722$ & 0,478 & & $-1,510$ & 0,141 & & \\
\hline & $\mathrm{CR}$ & 0,026 & 0,099 & 0,043 & 0,264 & 0,793 & 0,746 & 1,341 \\
\hline & DER & $-0,283$ & 0,398 & $-, 0,116$ & $-0,712$ & 0,482 & 0,756 & 1,323 \\
\hline & TATO & 1,241 & 0,301 & 0,588 & 4,127 & 0,000 & 0,982 & 1,019 \\
\hline
\end{tabular}

Variabel CR memiliki nilai t-hitung sebesar 0,264 dengan tingkat signifikan sebesar 0,793. Nilai statistik uji t-hitung lebih kecil dari t-tabel $(0,264<2,037)$ dan nilai signifikansi lebih besar dari $\alpha=(0,05)$ maka diperoleh Ho diterima dan Ha ditolak. hal ini berarti variabel Curent Ratio tidak berpengaruh signifikan terhadap pertumbuhan laba.

Variabel DER memiliki statistik uji t sebesar -0,712 dengan tingkat signifikan sebesar 0,482. Nilai statistik uji t-hitung lebih besar dari t-tabel $(-0,712<2,037)$ dan nilai signifikansi lebih besar dari $\alpha=(0,05)$ maka diperoleh Ho diterima dan Ha ditolak. hal ini berarti variabel Debt to Equity Ratio tidak berpengaruh signifikan terhadap pertumbuhan laba.

Variabel TATO memiliki statistikuji t sebesar 4,127 dengan tingkat signifikan sebesar 0,000. Nilai statistik uji t-hitung lebih besar dari t-tabel $(4,127>2,037)$ dan nilai signifikansi lebih kecil dari $\alpha=(0,05)$ maka diperoleh Ho ditolak dan Ha diterima. hal ini berarti variabel Total Assets Turnover Ratio berpengaruh signifikan terhadap pertumbuhan laba.

\section{Uji Koefisien Determinasi $\left(\mathbf{R}^{2}\right)$}

Tabel 10

Uji Koefisien Determinasi $\left(\mathrm{R}^{2}\right)$

\begin{tabular}{|c|c|r|r|c|}
\hline \multicolumn{6}{|c|}{ Model Summary } \\
\hline Model & $\mathrm{R}$ & R Square & $\begin{array}{c}\text { Adjusted R } \\
\text { Square }\end{array}$ & $\begin{array}{c}\text { Std. Error of } \\
\text { the } \\
\text { Estimate }\end{array}$ \\
\hline 1 & $0,601^{\mathrm{a}}$ & 0,361 & 0,301 &, 44700 \\
\hline $\begin{array}{l}\text { a. Predictors: (Constant), TATO, DER, CR } \\
\text { b. Dependent Variable : Pertumbuhan Laba }\end{array}$ \\
\hline
\end{tabular}

Nilai koefisien determinasi (adjusted) $\mathrm{R}^{2}$ ) sebesar 0,301 atau sebesar 30\%. Hal ini berarti variabel CR, DER, dan TATO mempengaruhi variabel Pertumbuhan Laba sebesar 30\% sedangkan sisanya $70 \%$ dipengaruhi oleh faktor - faktor lain yang tidak dimasukkan dalam model regresi pada penelitian ini. 


\section{PEMBAHASAN DAN HASIL INTERPRETASI HASIL PENELITIAN \\ Pengaruh Current Ratio (CR) terhadap pertumbuhan laba}

Hasil pengujian pada penelitian ini memperlihatkan bahwa nilai signifikansi sebesar 0,793. lebih besar dari tingkat signifikansi $\alpha=0,05$. Selain itu, nilai t- hitung 0,264 lebih rendah dari t-tabel 2,037. Berdasarkan pengujian ini maka disimpulkan bahwa CR tidak berpengaruh terhadap pertumbuhan laba. Kondisi ini mengartikan bahwa CR yang rendah terjadi karena utang jangka pendek yang harus di penuhi lebih banyak dari asset lancar yang dimiliki perusahaan. Sedangkan nilai CR yang terlalu tinggi, belum tentu berdampak baik bagi perusahaan dikarenakan perusahaan tidak mampu mengalokasikan asset lancar yang dimiliki secara efektif maka menyebabkan adanya dana menganggur, sehingga menurunkan laba perusahaan. Dana menganggur disebabkan oleh perusahaan menginvestasikan sebagian besar dana yang dimilikinya pada asset lancarnya. Artinya manajemen kurang mampu dalam mengoperasikan aktivitas perusahaan secara baik, terutama dalam penggunaan dana yang dimiliki. Hal ini pada akhirnya sudah dipastikan akan berpengaruh terhadap pencapaian laba yang dihasilkan, dari hal tersebut menyebabkan CR tidak berpengaruh terhadap pertumbuhan laba.

\section{Pengaruh Debt to Equity Ratio (DER) terhadap pertumbuhan laba.}

Hasil pengujian pada penelitian ini memperlihatkan bahwa nilai signifikansi sebesar 0,482 lebih besar dari tingkat signifikansi $\alpha=0,05$. Selain itu, nilai t-hitung $-0,712$ lebih rendah dari t-tabel 2,037. Berdasarkan pengujian ini maka disimpulkan bahwa DER tidak berpengaruh terhadap pertumbuhan laba. Kondisi ini mengartikan bahwa DER yang tinggi menyebabkan tingginya utang perusahaan dan menimbulkan beban bunga yang semakin besar. Berarti struktur modal perusahaan di pengaruhi oleh utang dibandingkan dengan modalnya. pengaruh atas utang akan menimbulkan dampak atas kelangsungan hidup perusahaan, terutama pada peningkatan keuntungan yang akan di peroleh. Hal ini akan mengakibatkan besarnya resiko yang akan terjadi bagi perusahaan jika tidak mampu melunasi kewajiban yang segara jatuh tempo. Sehingga kegiatan operasional akan terganggu dan menurunkan laba perusahaan, dari hal tersebut menyebabkan DER tidak berpengaruh terhadap pertumbuhan laba.

\section{Pengaruh Total Assets Turnover (TATO) terhadap pertumbuhan laba.}

Hasil pengujian yang telah dilakukan, pada hasil penelitian ini menunjukkan bahawa nilai signifikansi sebesar 0,000 lebih kecil dibandingkan dengan tingkat signifikansi $\alpha=0,05$. Selain itu, nilai t- hitung sebesar 4,233 lebih tinggi dari t-tabel sebesar 2,037. Berdasarkan pengujian ini maka disimpulkan bahwa TATO berpengaruh signifikan terhadap pertumbuhan laba. Kondisi ini mengartikan perusahaan memanfaatkan seluruh aktivitasnya yang mempengaruhi produksi dalam melakukan penjualan untuk mencapai laba sudah maksimal. Sehingga seluruh aktiva sudah dikelola oleh perusahaan secar efektif, dari hal tersebut menyebabkan TATO berpengaruh terhadap pertumbuhan laba

\section{PENUTUP}

\section{Kesimpulan}

a. Berdasarkan uji F, maka diketahui secara simutan nilai signifikan sebesar 0,002 lebih kecil dari taraf signifikansi 0,05. Selain itu nilai F-hitung sebesar 6,031 lebih besar dari nilai F-tabel 2,89. Maka dapat disimpulkan secara simultan terdapat pengaruh signifikan antara variabel independent (CR, DER, TATO) terhadap variabel dependen 
(pertumbuhan laba) pada perusahaan manufaktur industri dasar dan kimia yang terdaftar di BEI periode tahun 2017 - 2020.

b. Current Ratio (CR) secara parsial tidak berpengaruh signifikan terhadap pertumbuhan laba pada perusahaan manufaktur industri dasar dan kimia yang terdaftar di BEI periode tahun 2017 - 2020 dilihat dari nilai signifikansi sebesar 0,793 lebih besar dari taraf signifikansi sebesar 0,05 , dan t hitung sebesar 0,264 lebih rendah dari nilai t tabel sebesar 2,037

c. Debt to Equity Ratio (DER) secara parsial tidak berpengaruh signifikan terhadap pertumbuhan laba pada perusahaan manufaktur industri dasar dan kimia yang terdaftar di BEI periode tahun 2017 - 2020 dilihat dari nilai signifikansi sebesar 0,482 lebih besar dari taraf signifikansi sebesar 0,05 , dan t hitung sebesar $-0,712$ lebih rendah dari nilai t tabel sebesar 2,037.

d. Total Assets Turnover (TATO) secara parsial berpengaruh signifikan terhadap pertumbuhan laba pada perusahaan manufaktur industri dasar dan kimia yang terdaftar di BEI periode tahun 2017 - 2020 dilihat dari nilai signifikansi sebesar 0,000 lebih kecil dari taraf signifikansi sebesar 0,05, dan thitung sebesar 4,127 lebih tinggi dari nilai t tabel sebesar 2,037.

\section{Saran}

a. Penelitian yang akan datang sebaiknya menambahkan variabel - variabel kain yang digunakan dalam penelitian seperti NPM, DAR, ROI sebagai faktor - faktor lain yang memberikan gambaran mengenai Pertumbuhan Laba selain dari ketiga variable yang digunakan sebelumnya.

b. Perusahaan perlu memperhatikan tingkat Current Ratio (CR) dalam hal ini adalah pengelolaan asset lancar, karena tingkat Current Ratio (CR) yang telalu tinggi belum tentu berdampak baik terhadap pertumbuhan laba karena mengindikasi terdapat dana yang menganggur.

c. Bagi para investor sebaiknya dalam menilai kinerja perusahaan tidak hanya mengacu pada pertumbuhan laba saja, akan tetapi perhatikan juga faktor- faktor lain yang mempengaruhinya agar menciptakan hasil yang tepat dalam pengambilan keputusan untuk melakukan investasi pada suatu perusahaan. Dalam hasil penelitian ini rasio yang berpengaruh terhadap pertumbuhan laba adalah Total Assets Turnover (TATO).

\section{DAFTAR PUSTAKA}

Dewan Standar Akuntansi Keuangan IAI. 2017. Standar Akuntansi Keuangan (SAK) No 14: Persediaan. Jakarta : Ikatan Akuntan Indonesia.

Fahmi, I. (2020). Analisis Laporan Keuangan. Bandung: Alfabeta.

Ghozali, I. (2018). Aplikasi Analisis Multivariate spss 25. Badan Peneribit Universitas Diponegoro.

Hery. (2018). Analisis Laporan Keuangan. Jakarta : Grasindo.

Jatmiko, D. P. (2017). Pengantar Manajemen Keuangan. Yogyakarta : Diandra Kreatif.

Kasmir. (2018). Analisis Laporan Keuangan. Depok : Rajawali Pers.

Musthafa. (2017). Manajemen Keuangan. Yogyakarta : CV Andi Offset. 
Sugiyono. (2019). Metode Penelitian Kuantitatif, Kualitatif dan R\&D. Penerbit Alfabeta Bandung.

Sujarweni, V. W. (2016). Kupas tuntas penelitian akuntansi dengan SPSS. Pustaka Baru Press.

Sudana, I. M. (2015). Praktik Manajemen Keuangan Perusahaan. Jakarta : Erlangga.

Wijaya, D. (2017). Manajemen Keuangan. Jakarta : Grasindo.

Aryanto, U. R., Titisari, K. H., \& Nurlaela, S. (2018). Pengaruh Likuiditas, Leverage, Profitabilitas, Dan Aktivitas Terhadap Pertumbuhan Laba (Studi Empiris: Perusahaan Food And Beverages Yang Terdaftar Di Bursa Efek Indonesia Periode 2011-2015) Ulfinabella. Seminar Nasional IENACO, 625-631.

Gautama, F. A. J., \& Hapsari, D. W. (2016). Pengaruh Net Profit Margin (npm), Total Asset Turnover (tato), Debt Equity Ratio (der) Terhadap Pertumbuhan Laba (studi Kasus Pada Perusahaan Sektor Infrastruktur, Utilitas, Dan Transportasi Yang Terdaftar Di Bursa Efek Indonesia Tahun 2011-2014). EProceedings of Management, 3(1).

Lestari, N., Chandra, J., Venessa, \& Darwin. (2019). Pengaruh Current Ratio (CR), Debt To Equity Ratio (DER), Return On Asset (ROA), dan Total Asset Turnover(TATO) Terhadap Pertumbuhan Laba Pada perusahaan sub Sektor Makanan Dan minuman Yang Tercatat Di BEI Periode 2012-2016. Jurnal Riset Akuntansi Multiparadigma, 6(1), 59-63.

Panjaitan, R. J. (2018). Pengaruh Current Ratio, Debt To Equity Ratio, Net Profit Margin Dan Return on Asset Terhadap Pertumbuhan Laba Pada Perusahaan Consumer Goods Yang Terdaftar Di Bursa Efek Indonesia Periode 2013-2016. Jurnal Manajemen, 4(1), 61-72.

Purwitasari, R. E., \& Soekotjo, H. (2019). Pengaruh Total Asset Turnover, Return On Asset, Dan Debt To Asset Ratio Terhadap Pertumbuhan Laba. Jurnal Ilmu Dan Riset Manajemen, 8(3), 1-15.

Puspasari, M. F., Suseno, Y. D., \& Sriwidodo, U. (2017). Pengaruh Current Ratio, Debt To Equity Ratio, Total Asset Turnover, Net Profit Margin, Dan Ukuran Perusahaan Terhadap Pertumbuhan Laba. Jurnal Manajemen Sumber Daya Manusia, 11(1), 121-133.

Sihombing, H. (2018). Pengaruh Current Ratio dan Debt to Equity Ratio Terhadap Pertumbuhan Laba Pada Perusahaan Properti dan Real Estate yang Terdaftar di Bursa Efek Indonesia Periode 2010-2014. Media Studi Ekonomi, 21(1), 1-20.

Sihura, M. M., \& Gaol, R. L. (2016). Pengaruh Rasio keuangan Terhadap Pertumbuhan laba Pada Perusahaan Retail Di BEJ. 2(2), 191-210. https://doi.org/10.37531/yume.vxix.234

Sulistyowati. (2017). Analisis Tato, Npm, Dan Roa Terhadap Pertumbuhan Laba Pada Perusahaan Food \& Beverage. Jurnal Ilmu Dan Riset Akuntansi , Volume 6,(April), 14391440. 